IOSR Journal of Pharmacy

e-ISSN: 2250-3013, p-ISSN: 2319-4219, www.iosrphr.org

Volume 2 Issue 6 || || Nov-Dec. 2012 || | PP.45-49

\title{
Sb (III) complexes derived from 5-phenyl-1H-imidazole-4- carbaldehyde and $O$ or $S$ containing dihydrazide with their antibacterial and spectroscopic studies
}

\author{
Gajendra Kumar $^{1 *}$,Vidhi Singh ${ }^{1}$, Kulvant Singh $^{2}$, Iftakhar Ahmad ${ }^{2}$, \\ Dharmendra Singh Yadav ${ }^{2}$, Amit Kumar ${ }^{2}$, Nupur Shishodia ${ }^{2}$ \\ ${ }^{1}$ Chemical Science Laboratory, BIT Muzaffarnagar 251315(UP) India, \\ ${ }^{2}$ Department of Chemistry Meerut College Meerut (U.P) 250001 India.
}

\begin{abstract}
Schiff base ligand $\left[\mathrm{C}_{21} \mathrm{H}_{18} \mathrm{~N}_{8} \mathrm{O}\right]$ was synthesized by reacting 5-phenyl-1H-imidazole-4carbaldehyde and $\mathrm{S}$ or $\mathrm{O}$ containing dihydrazide (2:1) and a series of metal complexes [ $\left.\mathrm{Sb}\left(\mathrm{C}_{21} \mathrm{H}_{18} \mathrm{~N}_{8} \mathrm{O}\right) \mathrm{Cl}\right] \mathrm{Cl}_{2}$, $\left[\mathrm{Sb}\left(\mathrm{C}_{21} \mathrm{H}_{18} \mathrm{~N}_{8} \mathrm{O}\right) \mathrm{NO}_{3}\right]\left(\mathrm{NO}_{3}\right)_{2},\left[\mathrm{Sb}\left(\mathrm{C}_{21} \mathrm{H}_{18} \mathrm{~N}_{8} \mathrm{O}\right) \mathrm{OAc}\right](\mathrm{OAcc})_{2,},\left[\mathrm{Sb}\left(\mathrm{C}_{21} \mathrm{H}_{18} \mathrm{~N}_{8} \mathrm{~S}\right) \mathrm{Cl}\right] \mathrm{Cl} l_{2},\left[\mathrm{Sb}\left(\mathrm{C}_{21} \mathrm{H}_{18} \mathrm{~N}_{8} \mathrm{~S}\right) \mathrm{NO}_{3}\right]\left(\mathrm{NO}_{3}\right)_{2}$, and $\left[\mathrm{Sb}\left(\mathrm{C}_{21} \mathrm{H}_{18} \mathrm{~N}_{8} \mathrm{~S}\right) \mathrm{OAc}\right](\mathrm{OAc})_{2}$ with the new ligands were synthesized by reaction with $\mathrm{Sb}$ (III) metal salt in methanolic medium. The Schiff base ligand and their metal complexes have been characterized with the help of elemental analysis, conductance measurements, magnetic measurements and their structure configuration has been determined by various spectroscopic (electronic, IR, ${ }^{1} \mathrm{H} N M R,{ }^{13} \mathrm{C} N M R, G C M S$ ) techniques. Electronic spectra of the complexes indicate that the geometry of the metal center was square pyramidal geometry. These metal complexes were also tested for their antibacterial activities to assess their inhibiting potential.
\end{abstract}

Keyword: Schiff base, Sb(III), Antibacterial activity.

\section{INTRODUCTION}

Transition metals are known to form Schiff base complexes and Schiff bases have often been used as chelating ligands in the field of coordination chemistry. Compound containing an azomethine group $(-\mathrm{CH}=\mathrm{N}-)$ are known as Schiff base [1]. They are usually formed by condensation of a primary amine with carbonyl compound (aldehyde/ketone) [1]. Schiff bases that contain aryl substituents are substantially more stable and more readily synthesized, while those which contain alkyl substituents are relatively unstable. Schiff bases of aliphatic aldehydes are relatively unstable and readily polymerizable [2]. Schiff bases appear to be important intermediates in a number of enzymatic reactions involving interaction of the amino group of an enzyme, usually that of a lysine residue, with a carbonyl group of the substrate [3]. Stereochemical investigations [4] carried out with the aid of molecular models showed that Schiff bases formed between methylglyoxal and the amino group of the lysine side chains of proteins can bend back in such a way towards the $\mathrm{N}$ atom of peptide groups that a charge transfer can occur between these groups and the oxygen atoms of the Schiff bases. Transition metals are known to form Schiff base complexes and Schiff bases have often been used as chelating ligands in the field of coordination chemistry. Their metal complexes have been of great interest for many years. It is well known that $\mathrm{N}$ and $\mathrm{S}$ atoms play a key role in the coordination of metals at the active sites of numerous metallobiomolecules [5]. Schiff base metal complexes have been widely studied because they have industrial, antifungal, antibacterial, anticancer, antiviral and herbicidal applications [6-11]. They serve as models for biologically important species and find applications in biomimetic catalytic reactions. Chelating ligands containing $\mathrm{N}, \mathrm{S}$ and $\mathrm{O}$ donor atoms show broad biological activity and are of special interest because of the variety of ways in which they are bonded to metal ions. It is known that the existence of metal ions bonded to biologically active compounds may enhance their activities [9-11]. Schiff base metal complexes have been known since the mid nineteenth century [12] and even before the general preparation of the Schiff bases ligands themselves. Schiff base metal complexes have occupied a central place in the development of coordination chemistry after the work of Jorgensen and Werner [13].

In the present work Schiff base ligand was synthesized by the condensation of 5-phenyl-1H-imidazole4-carbaldehyde and $\mathrm{N}$ or $\mathrm{S}$ containing hydrazide (carbonohydrazide, thiocarbonohydrazide) (2:1) and a series of metal salt were synthesized by the reaction of ligand with $\mathrm{Sb}(\mathrm{III})$ metal salt. 


\section{Synthesis of the ligand}

\section{EXPERIMENTAL}

The ligand was prepared by the condensation of 5-phenyl-1H-imidazole-4-carbaldehyde with thiocarbonohydrazide or carbonohydrazide. A mixture of ethanol/1, 2-dichloroethane (1:3) was used as a solvent in the presence of anhydrous magnesium sulphate as a dehydrating agent (scheme 1,2).

\section{Synthesis of ligand-1 [(1E,5E)-1,5-bis((5-phenyl-1H-imidazol-4-yl)methylene) carbonohydrazide]}

5-phenyl-1H-imidazole-4-carbaldehyde ( $2 \mathrm{mmol})$ in ethanol $(20 \mathrm{~mL})$ was added to a solution of carbonohydrazide $(1 \mathrm{mmol})$ in ethanol $(30 \mathrm{~mL})$ containing a few drops of concentrated $\mathrm{HCl}$. The reaction mixture was refluxed for $3 \mathrm{~h}$. The mixture was cooled to room temperature and the solvent removed under reduced pressure by rotavapour until a solid product was formed that was washed with cold ethanol and dried under vacuum. Melting point $130^{\circ} \mathrm{C}$, Yield $70-75 \%$ (scheme 1). ${ }^{1} \mathrm{H}$ NMR (300MHz, DMSO): $\delta=7.22-7.48(\mathrm{~m}$, $10 \mathrm{H}, \mathrm{Ar}-\mathrm{H}), 7.0(\mathrm{~s}, 2 \mathrm{H}, \mathrm{H}), 7.51(\mathrm{~s}, 2 \mathrm{x} 1 \mathrm{H}, \mathrm{CH}), 7.77(\mathrm{~d}, 2 \mathrm{x} 1 \mathrm{H},-\mathrm{NH}$, imidazole), $13.4(\mathrm{~d}, 2 \times 1 \mathrm{H},-\mathrm{NH}$ of imidazole)

${ }^{13} \mathrm{C}$ NMR (300MHz, DMSO, $\left.300 \mathrm{~K}\right): 139.3(\mathrm{C}=\mathrm{N}), 161.0(\mathrm{C}=\mathrm{O}), 145.7,135.8,133.1,129.3,128.8$, $127.5,122$,(aromatic carban). One quaternary carbon was not detected. UV/vis (Nujol mul (nm)): $\lambda=280,330$, 340. UV/vis $\left(1 \times 10^{-4} \mathrm{~mol}, \mathrm{DMSO}\right): \lambda=260,290,345$. IR $(\mathrm{KBr}): v\left(\mathrm{~N}^{2} \mathrm{H}\right) 3245, v(\mathrm{C}=\mathrm{O}), 1719,, v(\mathrm{C}=\mathrm{N}) 1678$, $v(\mathrm{~N}-\mathrm{N}) 1115 \mathrm{~cm}^{-1}$. Elemental analysis for $\mathrm{C}_{21} \mathrm{H}_{18} \mathrm{~N}_{8} \mathrm{O}$ (398.421): calcd. C 63.31, H 4.55, N 28.12; found C 63.35, H 4.52, N 28.10.

\section{Synthesis of Ligand-2 [(1E,5E)-1,5-bis((5-phenyl-1H-imidazol-4-yl)methylene) thiocarbonohydrazide]}

5-phenyl-1H-imidazole-4-carbaldehyde ( $2 \mathrm{mmol})$ in ethanol $(20 \mathrm{~mL})$ was added to a solution of thiocarbonohydrazide $(1 \mathrm{mmol})$ in ethanol $(30 \mathrm{~mL})$ containing a few drops of concentrated $\mathrm{HCl}$. The reaction mixture was refluxed for $3 \mathrm{~h}$. The mixture was cooled to room temperature and the solvent removed under reduced pressure by rotavapour until a solid product was formed that was washed with cold ethanol and dried under vacuum. Melting point $145^{\circ} \mathrm{C}$, Yield 70-75\% (scheme 2). ${ }^{1} \mathrm{H}$ NMR (300MHz, DMSO): $\delta=7.22-7.48(\mathrm{~m}$, $10 \mathrm{H}, \mathrm{Ar}-\mathrm{H}), 7.0(\mathrm{~s}, 2 \mathrm{H}, \mathrm{H}), 7.51(\mathrm{~s}, 2 \mathrm{x} 1 \mathrm{H}, \mathrm{CH}), 7.77(\mathrm{~d}, 2 \mathrm{x} 1 \mathrm{H},-\mathrm{NH}$, imidazole), $13.4(\mathrm{~d}, 2 \mathrm{x} 1 \mathrm{H},-\mathrm{NH}$ of imidazole)

${ }^{13} \mathrm{C}$ NMR (300MHz, DMSO, $\left.300 \mathrm{~K}\right): 139.3(\mathrm{C}=\mathrm{N}), 186.0(\mathrm{C}=\mathrm{S}), 145.7,135.8,133.1,129.3,128.8$, $127.5,122$,(aromatic carban). One quaternary carbon was not detected. UV/vis (Nujol mul (nm)): $\lambda=278,332$, 342. UV/vis $\left(1 \times 10^{-4} \mathrm{~mol}, \mathrm{DMSO}\right): \lambda=261,289,355$. IR $(\mathrm{KBr}): v\left(\mathrm{~N}^{2} \mathrm{H}\right) 3244, v(\mathrm{C}=\mathrm{S}), 719,, v(\mathrm{C}=\mathrm{N}) 1678 \mathrm{~s}$, $v(\mathrm{~N}-\mathrm{N}) 1144 \mathrm{~s} \mathrm{~cm}^{-1}$. Elemental analysis for $\mathrm{C}_{21} \mathrm{H}_{18} \mathrm{~N}_{8} \mathrm{~S}$ (414.486): calcd. C 60.85, H 4.38, N 27.03; found C $60.88, \mathrm{H} 4.42$, N 27.13.

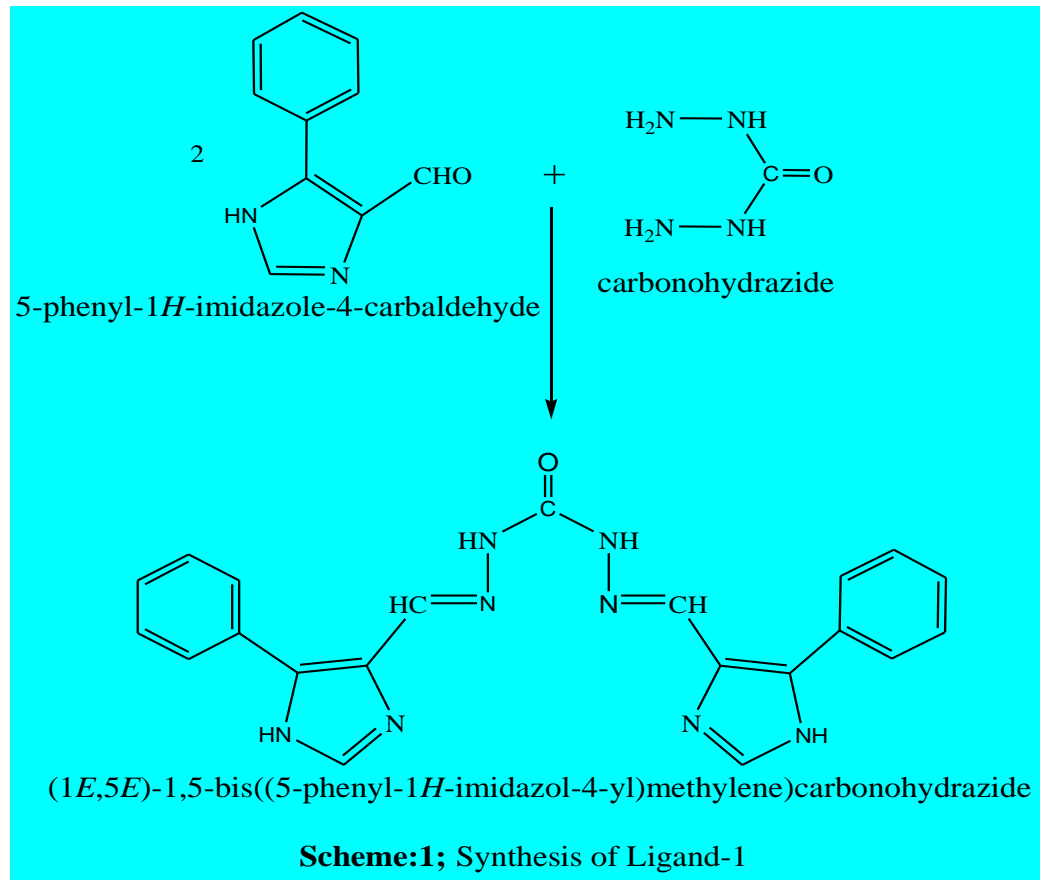




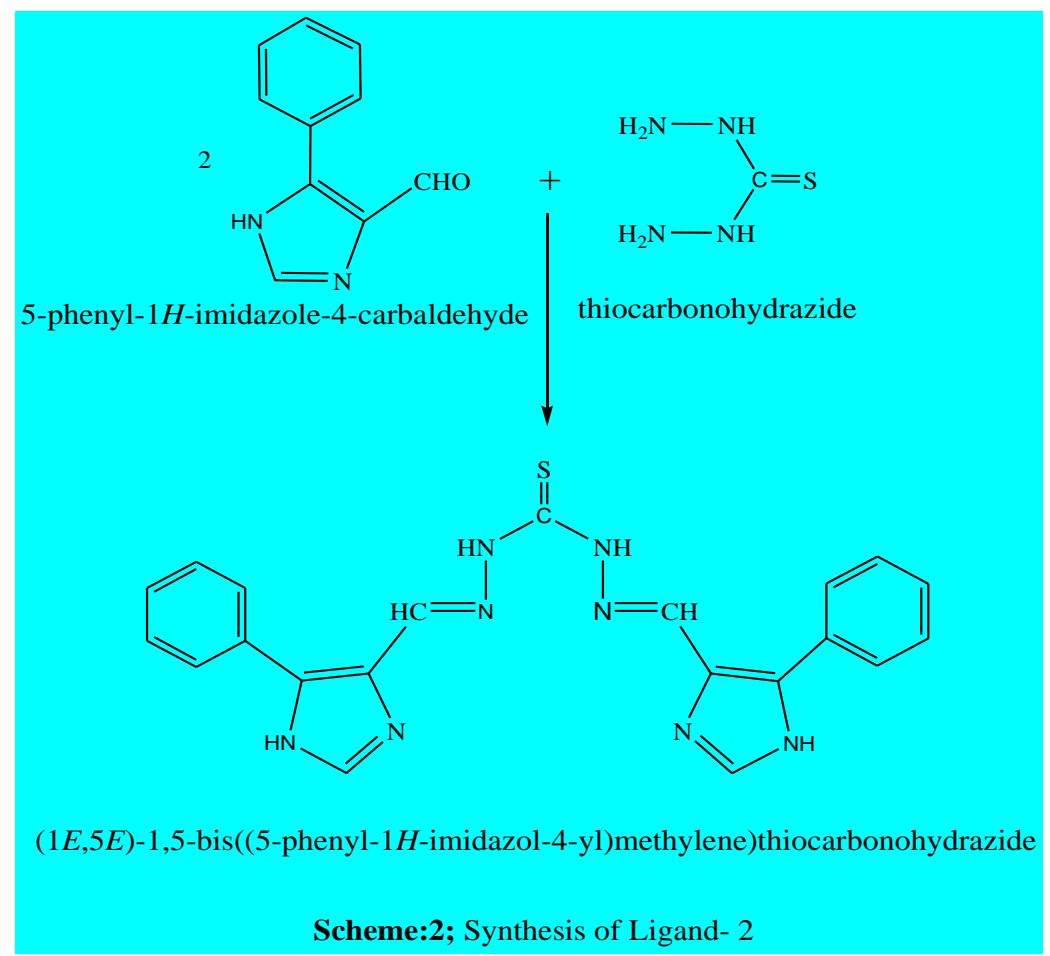

\section{Synthesis of the metal complexes}

The metal complexes of the ligand HL $(1,2)$ were prepared by mixing a hot methanolic solution of the $\mathrm{Sb}$ (III)metal salts with required amount of a hot ethanolic solution of the ligand to form metal/ligand complexes (Scheme).

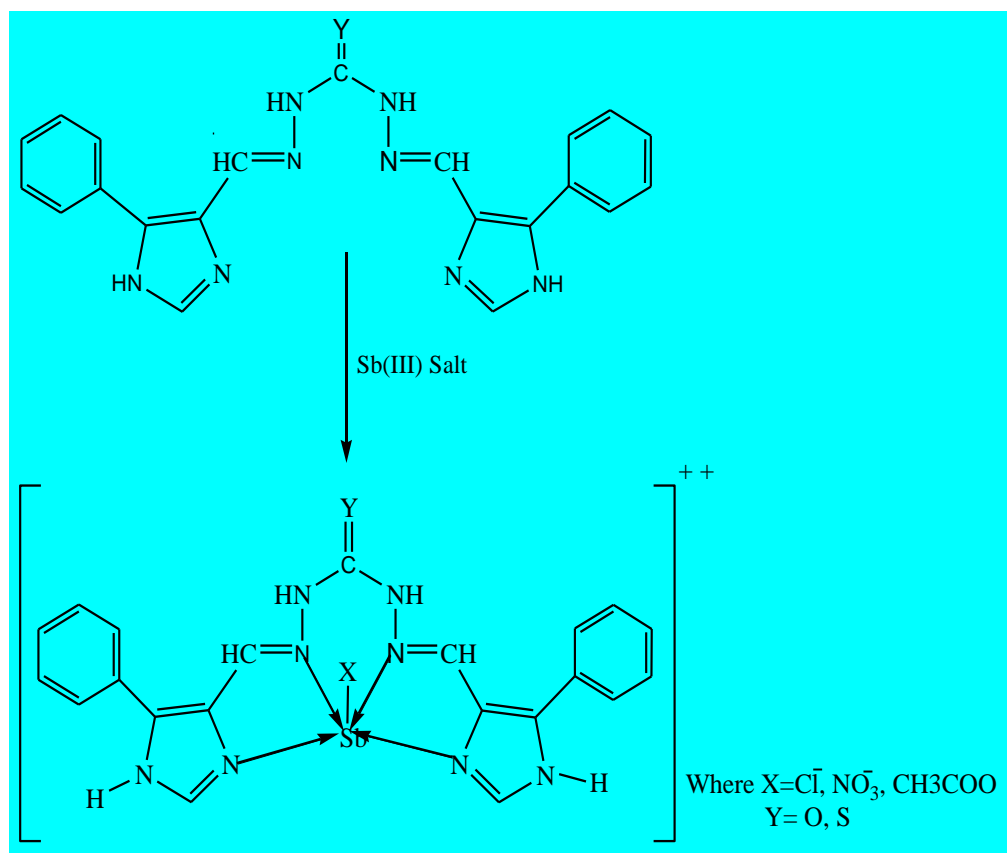

Synthesis of the metal complex (1)

Scheme: 3; Synthesis of the metal complex

Synthesis of $\mathrm{HLSbCl}_{3}$ complex (13). A solution of $\mathrm{SbCl}_{3} \cdot 2 \mathrm{H}_{2} \mathrm{O}$ in methanol (10 ml) was added to a hot solution $\left(75^{\circ} \mathrm{C}\right)$ of $\mathrm{HL}(1)$ in ethanol $(22 \mathrm{~mL})$, and the reaction mixture was refluxed for $5 \mathrm{~h}$. The solution was concentrated under vacuum. The precipitate was filtered off, washed with methanol and dried under vacuum over anhydrous $\mathrm{CaCl}_{2}$ (61\% yield). Conductance $\Lambda \mathrm{m}: 146 \Omega^{-1} \mathrm{~cm}^{2} \mathrm{~mol}^{-1}$. UV/vis (Nujol mul (nm)): $\lambda=260,272$, 325, 520, 724 and 1150. IR $(\mathrm{KBr}): v\left(\mathrm{H}_{2} \mathrm{O}\right) 3340, v\left(\mathrm{~N}^{2} \mathrm{H}\right) 3260, v(\mathrm{C}=\mathrm{O}) 1707, v(\mathrm{C}=\mathrm{N}) 1651, v(\mathrm{~N}-\mathrm{N}) 1123, v(\mathrm{M}-$ Cl) $295, v(\mathrm{M}-\mathrm{N}) 420, v(\mathrm{M}-\mathrm{O}) 500 \mathrm{~cm}^{-1}$. Elemental analysis for $\mathrm{C}_{21} \mathrm{H}_{18} \mathrm{Cl}_{3} \mathrm{~N}_{8} \mathrm{SbO}$ (626.54): calcd. $\mathrm{C} 40.26, \mathrm{H}$ 2.92, N 17.88, Sb 19.43; found C 40.28, H 2.91, N 17.82, Sb 19.48.

Synthesis of the metal complex (2) 
Synthesis of $\mathrm{HLSb}\left(\mathrm{NO}_{3}\right)_{3}$ complex (14). A solution of $\mathrm{Sb}\left(\mathrm{NO}_{3}\right)_{3} \cdot 6 \mathrm{H}_{2} \mathrm{O}$ in methanol $(15 \mathrm{~mL})$ was added to a hot solution $\left(75^{\circ} \mathrm{C}\right)$ of $\mathrm{HL}(1)$ in ethanol $(20 \mathrm{~mL})$, the reaction mixture was refluxed for $4 \mathrm{~h}$. The precipitate was filtered off, washed with methanol and dried under vacuum over anhydrous $\mathrm{CaCl}_{2}$ ( $70 \%$ yield). Conductance $1 \mathrm{~m}: 167 \Omega^{-1} \mathrm{~cm}^{2} \mathrm{~mol}^{-1}$. UV/vis (Nujol mul (nm)): $\lambda=260,280,320,450,700,1150$. IR (KBr): $v\left(\mathrm{H}_{2} \mathrm{O}\right) 3380, v\left(\mathrm{~N}^{2} \mathrm{H}\right)$ 3260, $v(\mathrm{C}=\mathrm{O})$ 1715, $v(\mathrm{C}=\mathrm{N})$ 1680, $v(\mathrm{~N}-\mathrm{N})$ 1146, v(M-N) 440,v(M-O) $500 \mathrm{~cm}^{-1}$. Elemental analysis for $\mathrm{C}_{21} \mathrm{H}_{18} \mathrm{~N}_{11} \mathrm{SbO}_{10}$ (706.195): calcd. C 35.72, H 2.57, N 21.82, Sb 17.24; found C 35.70, H $2.52, \mathrm{~N} 21.83, \mathrm{Sb} 17.22$.

\section{Synthesis of the metal complex (3)}

Synthesis of $\mathrm{HLSb}(\mathrm{OAc})_{3}$ complex (15). A solution of $\mathrm{Sb}(\mathrm{OAc})_{3} \cdot 4 \mathrm{H}_{2} \mathrm{O}$ in methanol $(10 \mathrm{~mL})$ was added to a hot solution $\left(75^{\circ} \mathrm{C}\right)$ of $\mathrm{HL}(1)$ in ethanol $(20 \mathrm{~mL})$, and the reaction mixture was refluxed for $6 \mathrm{~h}$. The precipitate was filtered off, washed with methanol and dried under vacuum over anhydrous $\mathrm{CaCl}_{2}$ (66\% yield). Conductance $A \mathrm{~m}: 158 \Omega^{-1} \mathrm{~cm}^{2} \mathrm{~mol}^{-1}$. UV/vis (Nujol mul (nm)): $\lambda=251,281,333,451,680$ and 1140 . IR (KBr): $v\left(\mathrm{H}_{2} \mathrm{O}\right)$ 3311, v $\left(\mathrm{N}^{2} \mathrm{H}\right)$ 3266, v(C=O) 1715), v(C=N) 1657, v(N-N) 1123, v(M-N) 470, v(M-O) $510 \mathrm{~cm}^{-1}$, $v_{\text {sym }}\left(\mathrm{OC}(\mathrm{O}) \mathrm{CH}_{3}\right) 1549, v_{\text {asym }}\left(\mathrm{OC}(\mathrm{O}) \mathrm{CH}_{3}\right) 1366 \mathrm{~cm}^{-1},\left(\Delta v=190 \mathrm{~cm}^{-1}\right)$. Elemental analysis for $\mathrm{C}_{27} \mathrm{H}_{27} \mathrm{~N}_{8} \mathrm{SbO}_{7}$ (697.313): calcd. C 46.51, H 3.90, N 16.07, Sb 17.46; found C 46.52, H 3.11, N 16.02, Sb 17.42.

\section{Synthesis of the metal complex (4)}

Synthesis of $\mathrm{HLSbCl}_{3}$ complex (16). A solution of $\mathrm{SbCl}_{3} \cdot 2 \mathrm{H}_{2} \mathrm{O}$ in methanol $(11 \mathrm{~mL})$ was added to a hot solution $\left(75^{\circ} \mathrm{C}\right)$ of $\mathrm{HL}(2)$ in ethanol $(28 \mathrm{~mL})$, the reaction mixture was refluxed for $5 \mathrm{~h}$. The precipitate was filtered off, washed with methanol and dried under vacuum over anhydrous $\mathrm{CaCl}_{2}$ (73\% yield). Conductance Am: $144 \Omega^{-1} \mathrm{~cm}^{2} \mathrm{~mol}^{-1}$. UV/vis (Nujol mul (nm)): $\lambda=260,331,467,652$ and 1061. IR (KBr): $v\left(\mathrm{H}_{2} \mathrm{O}\right) 3406$, $v\left(\mathrm{~N}^{2} \mathrm{H}\right) 3286, v(\mathrm{C}=\mathrm{S}) 750, v(\mathrm{C}=\mathrm{N}) 1651, v(\mathrm{~N}-\mathrm{N})$ 1145, $v(\mathrm{M}-\mathrm{N})$ 455. Elemental analysis for $\mathrm{C}_{21} \mathrm{H}_{18} \mathrm{~N}_{8} \mathrm{Cl}_{3} \mathrm{SbS}$ (642.605): calcd. C 39.25, H 2.82, N 17.44, Sb 18.95; found C 39.28, H 2.88, N 17.41, Sb 18.89.

\section{Synthesis of the metal complex (5)}

Synthesis of $\mathrm{HLSb}\left(\mathrm{NO}_{3}\right)_{3}$ complex (17). A solution of $\mathrm{Sb}\left(\mathrm{NO}_{3}\right)_{3} \cdot 6 \mathrm{H}_{2} \mathrm{O}$ in methanol (15mL) was added to a hot solution $\left(75{ }^{\circ} \mathrm{C}\right)$ of $\mathrm{HL}(2)$ in ethanol $(20 \mathrm{~mL})$, the reaction mixture was refluxed for $4.5 \mathrm{~h}$. The precipitate was filtered off, washed with methanol and dried under vacuum over anhydrous $\mathrm{CaCl}_{2}$ ( $80 \%$ yield). Conductance $4 \mathrm{~m}: 168 \Omega^{-1} \mathrm{~cm}^{2} \mathrm{~mol}^{-1}$. UV/vis (Nujol mul (nm)): $\lambda=260,280,320,450,700,1150$. IR (KBr): $v\left(\mathrm{H}_{2} \mathrm{O}\right)$ 3380, v( $\left.\mathrm{N}^{2} \mathrm{H}\right)$ 3260, v(C=S) 785, v(C=N) 1680, v(N-N) 1146, v(M-N) 440, v(M-O) $500 \mathrm{~cm}^{-1}$. Elemental analysis for $\mathrm{C}_{21} \mathrm{H}_{18} \mathrm{~N}_{11} \mathrm{O}_{9} \mathrm{SbS}$ (722.261): calcd. C 34.92, H 2.51, N 21.22, Sb 16.86; found C 34.70, H 2.52, N 21.19, Sb 16.88.

\section{Synthesis of the metal complex (6)}

Synthesis of $\mathrm{HLSb}(\mathrm{OAc})_{3}$ complex (18). A solution of $\mathrm{Sb}(\mathrm{OAc})_{3} \cdot 4 \mathrm{H}_{2} \mathrm{O}$ in methanol $(12 \mathrm{~mL})$ was added to a hot solution $\left(75^{\circ} \mathrm{C}\right)$ of $\mathrm{HL}(2)$ in ethanol $(25 \mathrm{~mL})$, the reaction mixture was refluxed for $5 \mathrm{~h}$. The precipitate was filtered off, washed with methanol and dried under vacuum over anhydrous $\mathrm{CaCl}_{2}$ ( $75 \%$ yield). Conductance $\Lambda \mathrm{m}: 152 \Omega^{-1} \mathrm{~cm}^{2} \mathrm{~mol}^{-1}$. UV/vis (Nujol mul (nm)): $\lambda=265,280,340,489,636,1051$. IR (KBr): $v\left(\mathrm{H}_{2} \mathrm{O}\right)$ 3419, v( $\left.\mathrm{N}^{2} \mathrm{H}\right)$ 3277, v(C=S) 840, v(C=N) 1641, v(N-N) 1122, v(M-N) 460, v(M-O) $525 \mathrm{~cm}^{-1}$ $v_{\text {sym }}\left(\mathrm{OC}(\mathrm{O}) \mathrm{CH}_{3}\right) 1561, v_{\text {asym }}\left(\mathrm{OC}(\mathrm{O}) \mathrm{CH}_{3}\right) 1370 \mathrm{~cm}^{-1},\left(\Delta v=192 \mathrm{~cm}^{-1}\right)$. Elemental analysis for $\mathrm{C}_{27} \mathrm{H}_{27} \mathrm{~N}_{8} \mathrm{O}_{6} \mathrm{SbS}$ (713.378): calcd. C 45.46, H 3.81, N 15.71, Sb 17.07; found C 45.50, H 3.79, N 15.75, Sb 17.10.

\section{${ }^{1}$ H NMR Spectra}

\section{RESULTS AND DISCUSSION}

A survey of literature reveals that the NMR spectroscopy has been proved useful in establishing the structure and nature of many Schiff base ligand and their complexes. The ${ }^{1} \mathrm{H}$ NMR spectra of Schiff base ligand (HL) was recorded in $\mathrm{d}_{6}$-dimethylsulfoxide (DMFO- $\mathrm{d}_{6}$ ) solution using $\mathrm{Me}_{4} \mathrm{Si}$ (TMS) as internal standard. The ${ }^{1} \mathrm{H}$ NMR spectra of the ligand shows broad signal at 9.4-12.1 ppm due to the $-\mathrm{NH}$ [14]. The multiplets in the region 7.54-8.76 ppm may be assigned to aromatic proton $[15,17]$

${ }^{13} \mathrm{C}$ NMR of the Schiff base ligand, the signal appeared in the region 113-158 are assigned to aromatic carbon. The signal at 198.3-185.6, 182.8-171.2, 165.4-150.7 and 148.1- $15.8 \mathrm{ppm}$ are due to $\mathrm{C}=\mathrm{S}, \mathrm{C}=\mathrm{N}, \mathrm{C}=\mathrm{O}$ and $\mathrm{CH}_{3}$ respectively.

\section{Mass spectra}

The FAB mass spectra of Schiff base ligand and Sb (III) Schiff base complexes have been recorded. The molecular ion $\left(\mathrm{M}^{+}\right)$peaks obtained from various complexes are as follows: $\mathrm{m} / \mathrm{z}=398.42 \mathrm{C}_{21} \mathrm{H}_{18} \mathrm{~N}_{8} \mathrm{O}$ (ligand 1), $\mathrm{m} / \mathrm{z}=414.48 \mathrm{C}_{21} \mathrm{H}_{18} \mathrm{~N}_{8} \mathrm{~S}$ (ligand 2), $\mathrm{m} / \mathrm{z}=626.54\left[\mathrm{Sb}\left(\mathrm{C}_{21} \mathrm{H}_{18} \mathrm{~N}_{8} \mathrm{O}\right) \mathrm{Cl}\right] \mathrm{Cl}_{2}$ (complex 1), $\mathrm{m} / \mathrm{z}=706.19$ $\left[\mathrm{Sb}\left(\mathrm{C}_{21} \mathrm{H}_{18} \mathrm{~N}_{8} \mathrm{O}\right) \mathrm{NO}_{3}\right]\left(\mathrm{NO}_{3}\right)_{2}$ (complex 2), $\mathrm{m} / \mathrm{z}=697.31\left[\mathrm{Sb}\left(\mathrm{C}_{21} \mathrm{H}_{18} \mathrm{~N}_{8} \mathrm{O}\right) \mathrm{OAc}\right](\mathrm{OAc})_{2}($ complex 3), $\mathrm{m} / \mathrm{z}=642.60$ 
$\left[\mathrm{Sb}\left(\mathrm{C}_{21} \mathrm{H}_{18} \mathrm{~N}_{8} \mathrm{~S}\right) \mathrm{Cl}\right] \mathrm{Cl}_{2}$ (complex 4), $\mathrm{m} / \mathrm{z}=722.26\left[\mathrm{Sb}\left(\mathrm{C}_{21} \mathrm{H}_{18} \mathrm{~N}_{8} \mathrm{~S}\right) \mathrm{NO}_{3}\right]\left(\mathrm{NO}_{3}\right)_{2}$ (complex 5), $\mathrm{m} / \mathrm{z}=713.37$ $\left[\mathrm{Sb}\left(\mathrm{C}_{21} \mathrm{H}_{18} \mathrm{~N}_{8} \mathrm{~S}\right) \mathrm{OAc}\right](\mathrm{OAc})_{2}$ (complex 6). This data is in good agreement with the proposed molecular formula for these complexes. In addition to the peaks due to the molecular ion, the spectra exhibit peaks assignable to various fragments arising from the thermal cleavage of the complexes. The peak intensity gives an idea of the stability of the fragments.

\section{Electronic spectral studies, magnetic measurements and molar conductance}

The electronic spectra of Sb (III) complexes showed absorption band in the region 8950-9310, 13,15013,520, 17,550-18,450 and 27,380-27,780 $\mathrm{cm}^{-1}$ attributed to ${ }^{4} \mathrm{~B}_{1 \mathrm{~g}} \rightarrow{ }^{4} \mathrm{E}_{1 \mathrm{~g}},{ }^{4} \mathrm{~B}_{1 \mathrm{~g}} \rightarrow{ }^{4} \mathrm{~B}_{2 \mathrm{~g}}, \mathrm{~B}_{1 \mathrm{~g}} \rightarrow{ }^{4} \mathrm{~A}_{2 \mathrm{~g}}$ and ${ }^{4} \mathrm{~B}_{1 \mathrm{~g}} \rightarrow$ ${ }^{4} \mathrm{E}_{\mathrm{g}}$. The spectral bands are consistent with that of five coordinated Sb (III) complexes [18]. On the bases of spectral studies of these complexes, a five coordinated square pyramidal geometry and $\mathrm{C}_{4 \mathrm{v}}$ symmetry may be assigned for these complexes [19,20]. The magnetic moment value for this complex was found to be 3.68-4.93 B.M. at room temperature which is close to the predicted values for three unpaired electrons in the metal ions [21].

\section{Antibacterial activity}

Antibacterial activity was determined by Agar-ditch method. The investigated microorganisms were Pseudomonas aeruginosa, Proteus vulgaris, Proteus microbiles, Klebsiella pneumoniae and Staphylococcus aureus. The metal complexes were dissolved in the solvent DMF to obtained final concentration $1 \mathrm{mg} / 0.1 \mathrm{ml}$. A loop full of the given test strain was inoculated in $30 \mathrm{ml}$ of nutrient broth and incubated for 24 hour in an incubator at $30^{\circ} \mathrm{C}$ in order to activate the bacterial strain activity. $18-20 \mathrm{ml}$ of the nutrient agar media was added in to a $100 \mathrm{~mm}$ diameter pantry-plate. $0.1 \mathrm{ml}$ of the activated strain was inoculated in to the media when it reaches the temperature of $40^{\circ} \mathrm{C}$. The medium was allowed to solidify. After solidification of the media a hole was made in the plates with the help of a cup-borer, which was then filled with one of the test sample solution. The plates were incubated for 24 hours at $35^{\circ} \mathrm{C}$. The inhibition zone formed by these compounds against the particular test bacterial strain determined the antibacterial activity of the synthetic complexes. The complex (6) $\left[\mathrm{Sb}\left(\mathrm{C}_{21} \mathrm{H}_{18} \mathrm{~N}_{8} \mathrm{~S}\right) \mathrm{OAc}\right](\mathrm{OAc})_{2}$ shows the best antimicrobial activity against all the test strain. The mean value obtained for three individual replicates was used to calculate the zone of growth inhibition of each sample.

\section{CONCLUSION}

The analytical data showed a single metal ion mononuclear square pyramidal geometry of the $\mathrm{Sb}(\mathrm{III})$ complexes. These complexes were tested for their antibacterial inhibition potential against some pathogens studies reveals that, metal complexes (6) $\left[\mathrm{Sb}\left(\mathrm{C}_{21} \mathrm{H}_{18} \mathrm{~N}_{8} \mathrm{~S}\right) \mathrm{OAc}\right](\mathrm{OAc})_{2}$ have more biological activity.

[1]. H. Schiff, Ann. Suppl., 31864343.

\section{REFERENCES}

[2]. J. Hine, C.Y. Yeh, J. Am. Chem. Soc. 89 (1967) 2669.

[3]. A.L. Lehlinger, Worth, New York, 1975.

[4]. P. Otto, J. Ladik, Proc. Nat. Acad. Sci. USA 75 (1978) 3548.

[5]. D.H. Brown, W.E. Smith, London, 1990.

[6]. K. Singh, M.S. Barwa, P. Tyagi, Eur. J. Med. Chem. 42 (2007) 394.

[7]. P.G. Cozzi, Chem. Soc. Rev. 33 (2004) 410.

[8]. S. Chandra, J. Sangeetika, J. Indian Chem. Soc. 81 (2004) 203.

[9]. M.B. Ferrari, S. Capacchi, G. Pelosi, G. Reffo, P. Tarasconi, R. Albertini, S. Pinelli, P. Lunghi, Inorg. Chim. Acta 286 (1999) 134.

[10]. E. Canpolat, M. Kaya, J. Coord. Chem. 57 (2004) 1217.

[11]. M. Yildiz, B. Dulger, S.Y. Koyuncu, B.M. Yapici, J. Indian Chem. Soc. 81 (2004) 7.

[12]. H. Schiff, Ann. Chem. Pharm. 150, (1869) 193.

[13]. C.K. Jorgensen, Acta Chem. Scand. 11 (1957) 73.

[14]. D.P. Singh, V.B. Rana, Polyhedron 14 (1995) 2901-2906.

[15]. D.P. Singh, R. Kumar, J. Singh, Eur. J. of Med. Chem. 44 (2009) 1731-1736.

[16]. G. Kumar, S. Devi, R. Johari, D. Kumar, Eu. J.of Med. Chem. 52 (2012) 269-274

[17]. B.N. Figgis, J. Lewis, Prog. Inorg. Chem. 6 (1965) 37-239.

[18]. P. Zanello, S. Tamburini, P.A. Vigato, G.A. Mazzochin, Coord. Chem. Rev. 77 (1987) 165.

[19]. P.A. Vigato, S. Tamburini, D.E. Fenton, Coord. Chem. Rev. 106 (1990) 25.

[20]. D.E. Fenton, P.A. Vigato, Chem. Soc. Rev. 17 (1988) 89.

[21]. T.M. Sorrel, Tetrahedron 45 (1989) 3. 